\title{
The Effectiveness of Online Learning in Higher Education: A Survey of Undergraduate Students in Riau Archipelagos, Indonesia
}

\author{
Elsa Ernawati Nainggolan ${ }^{1 *}$, Susanti $^{2}$, Hanifah $^{3}$ \\ \{elsanainggolan@umrah.ac.id ${ }^{1}$, shanty@umrah.ac.id ${ }^{2}$, hanifah@umrah.ac.id ${ }^{3}$ \} \\ *Corresponding Author \\ Faculty of Teacher Training and Education, Universitas Maritim Raja Ali Haji, \\ Kepulauan Riau 29125 Indonesia
}

\begin{abstract}
Online learning became popular during the covid-19 pandemic and is essential in maintaining learning activities in higher education. This study aimed to analyze the students' perspectives on online learning effectiveness. The analysis involved identifying the online media used for classes, learning quality and satisfaction, and the students' learning preferences. The data were collected using a semi-structured questionnaire in an online survey from 125 students from five universities in Riau Archipelagos. The result showed that online classes should be limited to 1-2 hours to avoid monotonous learning. Furthermore, fewer studentteacher interactions affected learning success, hence blended learning was preferred.
\end{abstract}

Keywords: Effective Learning, Online Learning, Higher Education

\section{Introduction}

The Indonesian Ministry of Education and Culture ensured continuous learning activities amid the pandemic by implementing online learning. It is a virtual space that facilitates learning [1] using supporting tools. The basic requirements of the online learning system include electronic devices like laptops and smartphones, Internet connections, and educational platforms. The online system's effectiveness also depends on the teachers' and students' willingness to adapt. Therefore, their interactions and engagement improve the learning process.

Riau Archipelago province in Indonesia faces educational challenges due to its various remote islands limiting online learning. Several universities are located in the province's two largest islands, Batam and Tanjungpinang. The students from the remote islands are forced to learn from home, following the government regulations.

Most research focused on the online learning efficacy, such as the teachers and students in Jakarta were assessed on their readiness and ability to apply online learning and was found effective [2]. In Bandung, it was found that practical subjects could not be effectively conducted online [3]. 
However, the online learning effectiveness in the Riau Archipelagos has not been explored. This study provided a general overview of online learning efficacy in higher education in Riau Archipelagos, Indonesia. It also analyzed e-learning from the students' perspective. Comprehensive results in the various contexts will enlighten education practitioners and policymakers to evaluate online learning as an alternative solution.

\section{Method}

The research questions were answered through the survey method involving 125 students from five universities in Riau Archipelagos. The snowballing technique was applied in the participant's selection by requesting colleagues and relatives to distribute the questionnaire in google form in their respective universities. The participant criteria included active undergraduate students applying to online courses. The questionnaire consisted of 4 indicators described in nine questions; preferred online media, learning quality and satisfaction, and learning preference. The questionnaire on the online learning effectiveness in the Riau Archipelagos is displayed in table 1. The data was confidential and only used for research purposes, analyzed descriptively.

Table.1 The Questionnaire Indicators

\begin{tabular}{llcc}
\hline \multicolumn{1}{c}{ Variable } & \multicolumn{1}{c}{ Indicators } & Items & Total \\
\hline The effectiveness of & Media & 1,2 & 2 \\
online learning in the & Learning Quality & $3,4,5,6$ & 4 \\
Riau Archipelagos & Learning Satisfaction & 7,8 & 2 \\
& Learning Preference & 9 & 1 \\
\hline
\end{tabular}

\section{Result}

\subsection{Media}

Question 1 and 2 asked the students' media preference. Figure 1 shows that four common platforms were selected. Google Classroom was the most preferred at $67.4 \%$, whereas Zoom/google meet was the second choice at $65.1 \%$. Furthermore, $60.5 \%$ preferred WhatsApp, and $31.8 \%$ used YouTube. 


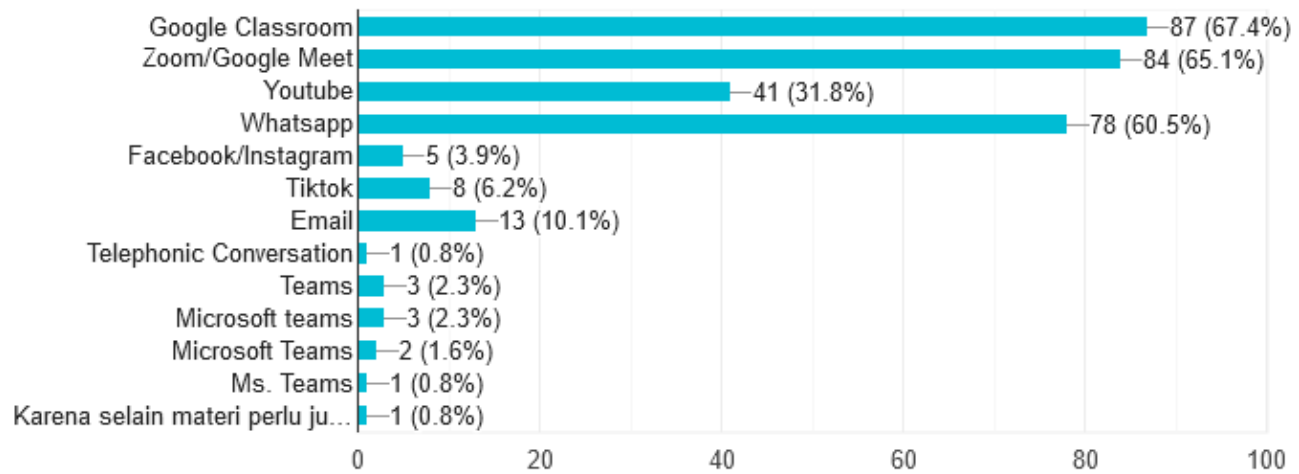

Fig.1. Students' preference of media While Learning Online

The students submitted their reasons for the preferred media, stating that they facilitated student-teacher interactions in the learning and teaching activities. The following selected-response supports the perspective:

"Google classroom eases the teacher's delivery of the learning materials and assignments. The app reminds students on submission deadlines for timely assignments submission. Google meet application facilitates the learning process where the teachers explains the material effectively. Online learning demands students to study independently, and the teachers uploads further explanations on YouTube for self-study. The students can find similar references in the app to enhance their understanding." (R1)

"In my opinion, using zoom or google meet makes student-teacher interactions better and students understands the teachers' explanation effectively even though the learning is conducted online. WhatsApp and YouTube are additional apps where the learning material can be distributed and easily accessed by students." (R2)

The participants were asked the ideal time for an online class, and the average response ranged from 1-2 hours. They argued that long classes caused exhaustion, boredom, lost focus, and spending a lot of internet quota. The comments are displayed as follow:

"I think the duration for effective learning conducted via zoom or google meet is an hour. More than that causes boredom, and gets worse when it lacks student's engagement." (R3) "Two hours because too much exposure from the screen could cause bad effect. I think there should be a break in between learning and conducting full-day class online must be avoided." (R4)

\subsection{Quality}


Learning quality also measures the online system effectiveness as asked in questions 3, 4, 5 , and 6 . The first question on learning quality was about the online learning disadvantages. Figure 2 shows the top five factors affecting online learning effectiveness. $74.4 \%$ stated that poor networks constrained the teaching and learning process. In contrast, $62 \%$ found spending a lot of internet quota as burdensome. 53.5\% felt that online learning reduced teachers' interaction, whereas $50.4 \%$ compared online learning to an enormous task, and $41.9 \%$ experienced boredom.

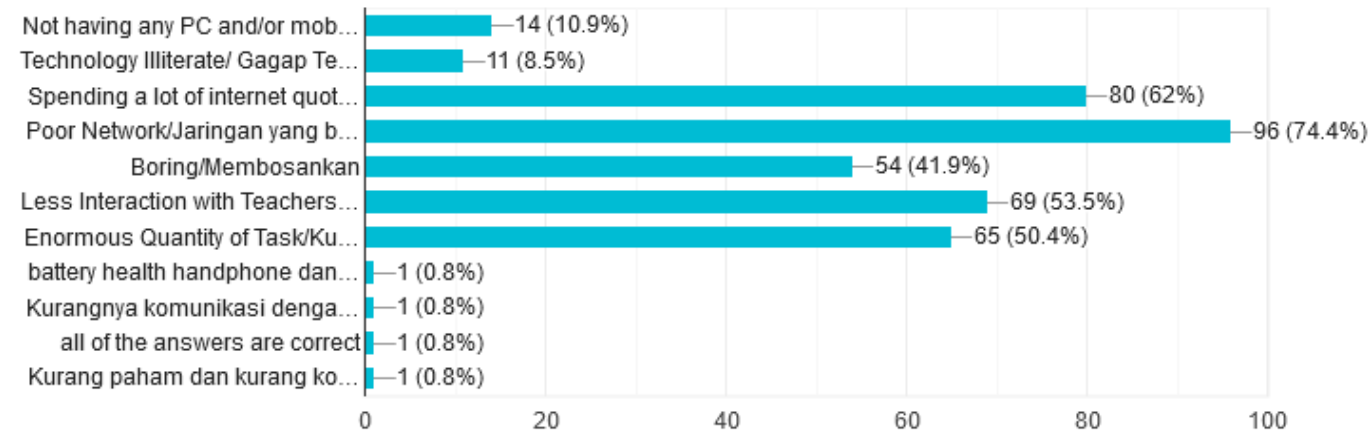

Fig.2. Students' opinion on the disadvantages of online learning

The responses were further investigated for elaborative students' reasons. Those comments are presented as follow:

"Many students live in the various islands in Riau archipelagos provinces. This condition causes bad weather which affects the network". (R5)

"I do not prefer online learning due to poor network. Teachers gave enormous task before the students understood the learning material." (R6)

"Some learning apps such zoom, google meet, and YouTube requires large internet quota. Some regions in Riau Archipelagos have poor networks which affects learning. Further explanation of learning material by the teacher is required because the students cannot comprehend the learning material with the minimal interactions. Contacting the teachers sometimes is less effective as they do not respond immediately." (R7)

Online learning advantages were also investigated. Figure 3 shows the top five advantages, with $62 \%$ stating that time flexibility enhanced online learning. 57,4\% agreed that it promoted students to learn independently, whereas $40.3 \%$ found it easily accessible and $27.9 \%$ cost-effective. 


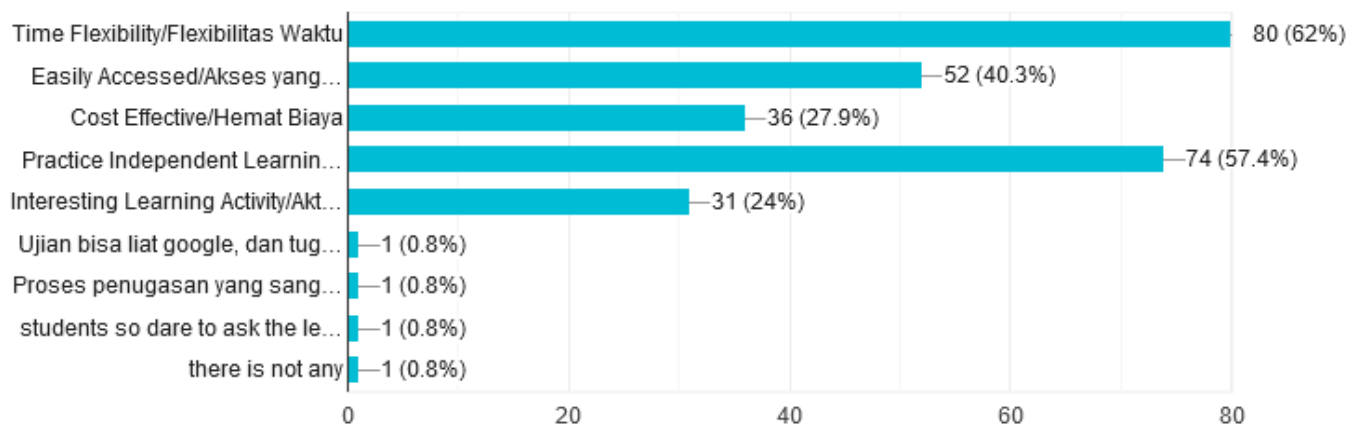

Fig.3. Students' opinion on the advantages of online learning

The following selected-response described the students' perceptions of those advantages.

"In my opinion, online learning is cost-effective because we are not required to be physically present in the classroom; hence saving rent money in the institutional environment. Online learning forces me to be independent as I have to perform most tasks individually." (R8)

"If we conduct the class online, we save some costs on transportation, meals, and boarding fee. online learning allows us to save because all the assignments could be submitted in efile depending on the teacher's instructions." (R9)

The students were asked about their teaching and learning process participation and whether online learning promotes active engagement through questions and responses. Figure 4 below shows that $45.7 \%$ were neutral, $26.4 \%$ agreed, and $20.2 \%$ disagreed.

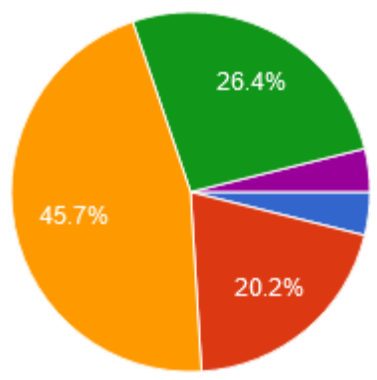

Strongly Disagree/Sangat tidak Setuju

Disagree/Tidak Setuju

Neutral/Netral

Agree/Setuju

Strongly Agree/Sangat Setuju

Fig.4. Online Learning activity triggers the students' participation in class

Their reasons are shown in the students' responses below: 
"I don't think online learning builds curiosity to ask questions because all instructions are always available." (R10)

"Due to fewer teacher-student interaction, question and answer activities are ineffective. Students sometimes do not comprehensively understand the learning material." (R11)

"In my opinion, I have not experienced that. Several challenges experienced by students hinders teachers from reaching them through the online class. Some do not want to ask questions, experience boredom, uninteresting lessons, or enough understanding." (R12)

The last question was the student's acceptance of learning material delivered by teachers through online learning. The figure below shows the results below at 38\% as good, $36.4 \%$ as fair, and $17.1 \%$ with poor acceptance.

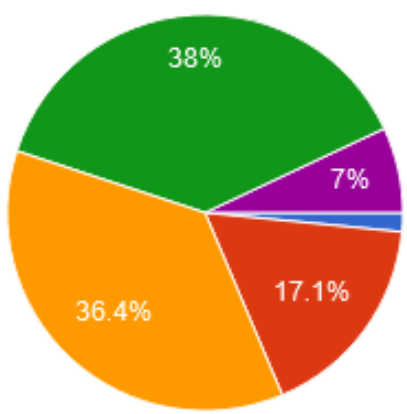

Very Poor/Sangat Kurang

Poor/Kurang

Fair/Cukup

Good/Baik

Excellent/Sangat Baik

Fig.5. The acceptance of learning material delivered by the teachers through online learning

The students' supporting responses are shown below.

"There are various ways for teachers to deliver the learning material, through videos, PowerPoint presentation, and video conference" (R13)

"The teaching and learning activities are usually interrupted by poor signal, affecting the acceptance of learning material." (R14)

"Long duration of the virtual meeting is boring and limits our willingness to participate." (R15)

\subsection{Satisfaction}

The students were asked about their satisfaction with their learning outcomes and their institution's online learning facilitation. This was asked in questions 7 and 8 , with question 7 investigating students' progress. Figure 6 below shows that $48.8 \%$ were neutral, and $33.3 \%$ agreed. These selected responses below present the perspectives:

"neutral. I could easily find the learning material that I did not understand on the internet." (R16)

"neutral. On one hand I like the flexibility of online learning but on the other, I hardly understand the material because of poor signal". (R17) 


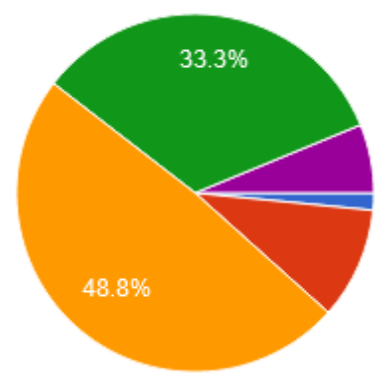

Strongly Disagree/Sangat tidak Setuju

Disagree/Tidak Setuju

Neutral/Netral

Agree/Setuju

Strongly Agree/Sangat Setuju

Fig.6. Satisfying students' achievement during the online learning

Question 8 asked the students' opinions on the overall teaching and learning process by the institution. This question shows the correlation between students' achievement and the institution's online learning services. Figure 7 shows that $41.1 \%$ were moderately satisfied, $27.1 \%$ were very satisfied, and $22.5 \%$ were slightly satisfied.

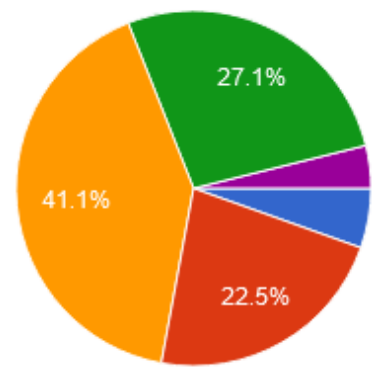

Not all satisfied/Sangat tidak puas

Slightly satisfied/Kurang puas

Moderately satisfied/Cukup puas

Very satisfied/Puas

Completely satisfied/Sangat puas

Fig.7. Online Learning Services performed by the institution

The students' response below supports the finding:

"The institution facilitates alternatives to complete the administration requirements. Some requirements are performed offline, but the institution allows other students to represent those living out of the island". (R18)

"The institution does not provide free zoom meeting access; hence we have limited time for the asynchronous class online." (R19)

"Some of the students have not received mobile data promised by the education ministry; hence some of us are not satisfied." (R20)

\subsection{Learning Preference}

Students' learning preference measures the effectiveness of online learning based on their experience in various learning environments. Therefore, their learning preference determines the 
effective methods. Figure 8 below shows that $41.1 \%$ preferred blended learning, $36.4 \%$ offline learning, and $22.5 \%$ online learning.

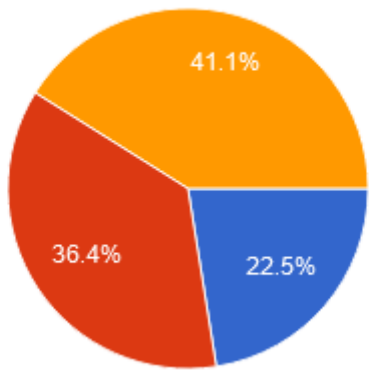

Online Learning/Pembejaran Daring

Offline Learning/Pembelajaran Luring

Blended Learning/Pembelajaran

Campuran

Fig.8. Students' Preference on Learning

The students' reasons were further investigated to provide deeper perspectives. The responses are presented as follows:

"Blended learning is more effective than other methods due to subjects that require offline classes. Subjects convenient for online learning can stay" (R21)

"I think blended learning is more effective and can be applied to reduce the crowd, some of us can sometimes meet for material discussions." (R22)

\section{Discussion}

The findings described online learning effectiveness in Riau Archipelagos. Following previous studies, most students selected Google Classroom, Zoom/Google Meet, WhatsApp, and YouTube as their preferred media [4]. The applications facilitate online learning, as shown by the students' response that they virtually communicate with fellow students and teachers through asking questions, performing assignments, and learning independently. However, the students argued that virtual meetings should be limited to 1-2 hours for effective learning. This follows the finding in 2021, that long virtual meetings drains energy which affects participants' engagement [5]. The lack of student involvement caused by fatigue from virtual meetings reduces learning outcomes and online learning effectiveness.

The learning quality is affected by students' lack of internet connectivity and inadequate learning environment, and alternative solutions are required. Teachers and students require great internet access to prevent online classes interruptions [6]. Therefore, third parties like the government should facilitate basic requirements for effective online learning. The students also experienced online learning advantages such as time flexibility despite poor internet connections.

The results showed that the students were neutral on whether the online system promotes an active learning process and the teachers' acceptance of the learning material. Therefore, online learning does not influence students' class engagements or learning material acceptance. Students 
revealed that this was because the learning environment by the teachers did not facilitate engagement. This can be solved by increased engagements by the teacher as the class protocol. Positive student - teacher interactions build students' intimacy and trust, increase their learning process contributions, and support their cognitive and learning outcomes [7].

Based on the analysis, the students were also neutral regarding online learning satisfaction. A previous study in 2017 found that students learning satisfaction positively affects the e-learning systems [8]. Learning satisfaction is measured through student productivity and timely completion of tasks. However, their neutral position showed that online learning is ineffective in their learning progress. Furthermore, this is contributed by the institution's online learning services. The students were moderately satisfied with the institution's learning facilities despite providing easy administration access. They were not provided with free zoom meeting access, and some did not receive mobile data to support their learning. Therefore, this challenge affected their achievement because student satisfaction significantly affects academic success. Students that are less satisfied with the institution have negative learning outcomes [9].

Consequently, students preferred and viewed the blended learning method as the right choice amid the pandemic. A similar finding reported in 2020 also revealed that the advantages of blended learning were flexibility, increased motivation, and interaction, and improved ICT skills [10]. Poor internet connection and incomprehensible materials that hindered the learning process can be solved through blending online and offline systems.

\section{Conclusion}

This study explored online learning effectiveness in higher education. Students found online learning ineffective showed through the learning quality and satisfaction. Furthermore, the students admitted that online classes caused fatigue. Despite the poor network and many quotas, the students managed their time and learned independently. They also benefited from minimized costs compared to offline classes. Fewer teacher interactions and engagements increased their dissatisfaction, hence, they preferred blended learning as an alternative.

Online learning has become popular amid the pandemic, however, education practitioners should effectively optimize the system. The main online learning challenge is to promote more active student-teacher interactions. The government should also facilitate internet network availability as the basic online learning requirement.

\section{References}

[1] Sathishkumar, V., Radha, R., Saravanakumar, A., \& K. Mahalakshmi. (2020). E-Learning during Lockdown of Covid-19 Pandemic: A Global Perspective. International Journal of Control and Automation, 13(June), 1088-1099.

[2] Simatupang N, Sitohang S, Situmorang A, Simatupang I. Efektivitas Pelaksanaan Pengajaran Online Pada Masa Pandemi Covid-19 Dengan Metode Survey Sederhana. J Din Pendidik. 2020;13(2):197203.

[3]. Hikmat, Hermawan E, Aldim, Irwandi. Efektivitas Pembalajaran Daring Selama Masa Pandemi 
Covid-19. Digit Libr UIN SUnan Gung Djati, Bandung [Internet]. 2020;1-7. Available from: http://digilib.uinsgd.ac.id/30625/

[4]. Shaharanee INM, Jamil JM, Rodzi ASSM. The application of Google Classroom as a tool for teaching and learning. J Telecommun Electron Comput Eng. 2016;8(10):5-8.

[5]. Shockley KM, Gabriel AS, Robertson D, Rosen CC, Chawla N, Ganster ML, et al. The fatiguing effects of camera use in virtual meetings: A within-person field experiment. J Appl Psychol. 2021;106(8):1137-55.

[6] Yusuf BN. Are We Prepared Enough? a Case Study of Challenges in Online Learning in a Private Higher Learning Institution During the Covid-19 Outbreaks. Adv Soc Sci Res J. 2020;7(5):205-12.

[7]. Pennings HJM, Hollenstein T. Teacher-Student Interactions, and Teacher Interpersonal Styles: A State Space Grid Analysis. J Exp Educ [Internet]. 2020;88(3):382-406. Available from: https://doi.org/10.1080/00220973.2019.1578724

[8] Aparicio, M., Bacao, F., \& Oliveira, T. (2017). Grit in the path to e-learning success. Computers in Human Behavior, 66, 388-399. https://doi.org/10.1016/j.chb.2016.10.009.

[9]. Basith A, Rosmaiyadi R, Triani SN, Fitri F. Investigation of Online Learning Satisfaction During COVID 19: Concerning Academic Achievement. J Educ Sci Technol. 2020;6(3):265-75.

[10] Aji WK, Ardin H, Arifin MA. Blended Learning During Pandemic Corona Virus: Teachers' and Students' Perceptions. IDEAS J English Lang Teach Learn Linguist Lit. 2020;8(2):632-46. 